\title{
ESPECIALIZAÇÃO REGIONAL PRODUTIVA E VULNERABILIDADE TERRITORIAL DOS MUNICÍPIOS SUCROENERGÉTICOS NO TRIÂNGULO MINEIRO/ALTO PARANAÍBA
}

\author{
Henrique Faria dos Santos \\ Doutorando em Geografia \\ Universidade Estadual de Campinas (UNICAMP), Campinas, SP, Brasil \\ livehenriquefariasantos@hotmail.com
}

\begin{abstract}
RESUMO
O presente artigo tem como objetivo analisar a especialização regional produtiva e a vulnerabilidade territorial de municípios sucroenergéticos no Triângulo Mineiro/Alto Paranaíba, região que teve forte crescimento da agroindústria sucroenergética entre 2000 e 2011. A sistematização teórica, estatístico-documental e de entrevistas permitiu concluir que vários municípios dessa região se tornaram altamente especializados e dependentes da produção e/ou processamento da cana-de-açúcar e de seus derivados industriais (açúcar, etanol e bioeletricidade), levando a um quadro preocupante de vulnerabilidade territorial, sobretudo naqueles municípios com baixo patamar demográfico e com pequenos núcleos urbanos. O engessamento do uso do território provocado pelo padrão espacial de ocupação da agroindústria sucroenergética resultou na diminuição da diversidade produtiva no campo e no atrelamento quase que exclusivo dos setores secundários e terciários ao funcionamento das usinas, representando diversas implicações socioeconômicas, como às que se efetivaram recentemente nos municípios de Canápolis, Capinópolis, Fronteira e lbiá que tiveram unidades desativadas.
\end{abstract}

Palavras-chave: Especialização regional produtiva. Vulnerabilidade territorial. Setor sucroenergético. Uso corporativo do território.

\section{PRODUCTIVE REGIONAL SPECIALIZATION AND TERRITORIAL VULNERABILITY OF SUGARCANE MUNICIPALITES IN THE TRIÂNGULO MINEIRO/ALTO PARANAÍBA}

\begin{abstract}
This article analyze the productive regional specialization and the territorial vulnerability of the sugarcane municipalities in the Triângulo Mineiro/Alto Paranaíba, a region that had a strong growth of sugarcane industry between 2000 and 2014. The theoretical and staticaldocumentary systematization and interviews allowed us to conclude that several municipalities in this region have became highly specialized and dependent of the production and/or processing of sugarcane and industrial derivate (sugar, ethanol and bioelectricity), resulting in a worrying state of territorial vulnerability, especially in small cities. The territory use plaster caused by spatial model of occupation of sugarcane industry in these places resulted in the reduction of the productive diversity in the rural space and the dependency almost exclusive of the secondary and tertiary sectors to the agroindustrial operating. It represents several social and economic implications, such as happened recently in Canápolis, Capinópolis, Fronteira and Ibiá that had sugarcane industry units deactivated.
\end{abstract}

Keywords: Productive regional specialization. Territorial vulnerability. Sugarcane industry. Corporative use of territory.

\section{INTRODUÇÃO}

O Triângulo Mineiro/Alto Paranaíba, mesorregião do estado de Minas Gerais, vem passando nos últimos anos por um intenso processo de especialização regional e territorial produtiva (SILVEIRA,

Caminhos de Geografia Uberlândia $\quad$ v. 20, n. $72 \quad$ Dez/2019 $\quad$ p. 169-188 Página 169


2010; 2011) calcado na produção e circulação de atividades ligadas ao agronegócio globalizado, como carne-grãos (pecuária, soja e milho), sucroenergético e café (SANTOS, 2019). Uma das atividades que mais contribuem para esse processo é o setor sucroenergético, que teve um grande crescimento na região entre 2000 e 2011, com os investimentos de corporações nacionais e transnacionais para a construção e/ou ampliação/modernização de unidades agroindustriais sucroenergéticas (UAS) e para a expansão das áreas de cultivo da cana-de-açúcar (PEREIRA, 2012; REIS, 2013; PETRONZIO, 2014; SANTOS, 2017).

Todavia, vários municípios tornaram-se altamente funcionais e dependentes da agroindústria sucroenergética, em decorrência do padrão "rígido" e "engessado" de uso do território apresentado por esta atividade econômica (CASTILLO, 2013), gerando várias implicações econômicas, sociais e ambientais. A vulnerabilidade territorial é praticamente inevitável no setor sucroenergético (CAMELINI; CASTILLO, 2012), já que extensas áreas de terras são ocupadas pela cana-de-açúcar e muitas das atividades ligadas aos setores secundário e terciário são voltadas quase que exclusivamente ao funcionamento das UAS, sobretudo em municípios de pequenos núcleos urbanos que criam um vínculo de extrema dependência econômica. Em casos de fechamento de UAS, como o que ocorreu em alguns municípios do Triângulo Mineiro/Alto Paranaíba (Canápolis, Capinópolis, Fronteira e Ibiá), os transtornos econômicos e sociais evidenciam essa problemática atrelada à alta especialização territorial produtiva dos municípios sucroenergéticos.

Nesse sentido, o presente artigo tem como objetivo discutir a vulnerabilidade territorial dos municípios sucroenergéticos do Triângulo Mineiro/Alto Paranaíba, visto as diversas implicações econômicas e socioambientais ligadas ao processo de especialização regional produtiva ocasionado pelo setor sucroenergético e o cenário de dificuldade econômica que o setor vem apresentando desde 2010 no Brasil, que tem corroborado no fechamento temporário e permanente de dezenas de UAS.

O estudo (SANTOS, 2017) apoiou-se na interlocução de três procedimentos: 1) levantamento e revisão bibliográfica (livros, artigos, teses e dissertações) sobre os conceitos de especialização regional produtiva e vulnerabilidade territorial, as características intrínsecas de ocupação espacial da agroindústria sucroenergética, a expansão do setor sucroenergético no Triângulo Mineiro/Alto Paranaíba, e as implicações socioeconômicas causadas pela desativação de UAS nos municípios; 2) pesquisa e sistematização documental e estatística de dados de municípios da região sobre as UAS instaladas (portais INFOCANA e NOVACANA, Anuário da Cana 2016), área, quantidade produzida, rendimento médio e valor da produção da cana-de-açúcar e demais cultivos (Pesquisa Agrícola Municipal - PAM / Instituto Brasileiro de Geografia e Estatística - IBGE), crédito rural de custeio total e da cana-de-açúcar (Banco Central do Brasil - BCB), participação do setor sucroenergético no valor das exportações (Ministério da Indústria, Comércio Exterior e Serviços - MDIC), na arrecadação fiscal (Secretaria de Estado da Fazenda de Minas Gerais - SEFAZ-MG) e no emprego formal (Relação Anual de Informações Sociais - RAIS / Ministério do Trabalho e Emprego - MTE), número de habitantes, extensão territorial e empresas ativas (IBGE Cidades), reportagens sobre a situação dos municípios que tiveram UAS recentemente desativadas (várias fontes), e área de cultivo da cana-deaçúcar nos municípios da região Centro-Sul (Agrosatélite Geotecnologia Aplicada, dados da União da Indústria de Cana-de-Açúcar - UNICA); 3) trabalhos de campo para execução de visitas técnicas, observações e entrevistas com sindicatos de trabalhadores e patronais, prefeituras, produtores rurais (plantadores de cana-de-açúcar ou arrendatários de terras para UAS) e moradores (urbanos e rurais) da região de Uberaba/MG e dos municípios de Canápolis/MG e Capinópolis/MG.

$\mathrm{O}$ artigo está dividido basicamente em três partes. A primeira aborda o processo de especialização regional produtiva no setor sucroenergético e a consequente vulnerabilidade territorial dos municípios funcionais à produção e/ou processamento da cana-de-açúcar, especialmente em relação aos eventuais casos de fechamento temporário ou permanente de UAS. A segunda parte trata de analisar, através de alguns dados como a evolução do número de UAS instaladas e da área de cultivo de cana-de-açúcar, o movimento de expansão do setor sucroenergético no Triângulo Mineiro/Alto Paranaíba. Já a terceira parte analisa a especialização territorial produtiva dos municípios sucroenergéticos da região e discute a vulnerabilidade territorial, tendo como exemplo os impactos socioeconômicos ocorridos em Canápolis, Capinópolis, Fronteira e Ibiá, localidades que se destacaram pela recente desativação de UAS.

$\begin{array}{llllll}\text { Caminhos de Geografia } & \text { Uberlândia } & \text { v. 20, n. } 72 & \text { Dez/2019 } & \text { p. 169-188 } & \text { Página } 170\end{array}$




\title{
ESPECIALIZAÇÃO REGIONAL PRODUTIVA E A VULNERABILIDADE TERRITORIAL DOS MUNICÍPIOS SUCROENERGÉTICOS NO BRASIL
}

No atual período da globalização econômica e financeira (BENKO, 1996; HIRST e THOMPSON, 1998; SANTOS, 2000; CHESNAIS, 2005), regiões, territórios e lugares selecionados se inserem eficientemente em diversos circuitos espaciais produtivos (SANTOS, 1986; CASTILLO e FREDERICO, 2010b) ao disponibilizar vantagens geográficas locacionais (naturais, geoeconômicas e político-normativo-institucionais) fundamentais à competitividade dos agentes produtivos. Para tanto, esses agentes, principalmente os mais capitalizados como as grandes corporações e instituições financeiras (nacionais e estrangeiras), necessitam ter acesso privilegiado e realizar usos diferenciados de ativos e recursos territoriais (BENKO e PECQUEUR, 2001) que proporcionem rentabilidade e fluidez em suas ações, efetivando um verdadeiro uso corporativo do território (SANTOS e SILVEIRA, 2001). E isto só se torna plenamente possível graças à estratégica cooperação com o Estado (SILVEIRA, 2011).

Gomes (2006, p. 27) destaca que "as vantagens competitivas de uma empresa ou de um país derivam do acesso diferenciado ou vantajoso a ativos que permitam que umas se organizem mais eficientemente que outras". Porém, cada agente possui distintas capacidades de obter essas vantagens. Para Santos e Silveira (2001, p. 260), "o território mostra diferenças de densidades quanto às coisas, aos objetos [naturais e artificiais], ao movimento das coisas, dos homens, das informações do dinheiro e também quanto às ações". Entretanto, os autores ponderam que cabe às empresas mais poderosas as melhores porções do território, isto é, às empresas dotadas de maior poder econômico e político, sendo que "os pontos do território em que elas se instalam constituem meras bases de operação, abandonadas logo que as condições deixam de lhes ser vantajosas" (SANTOS e SILVEIRA, 2001, p. 291). É possível então dizer que, por vezes, determinados espaços são (re) estruturados ou (re) qualificados para atender a certas demandas produtivas e comerciais das grandes empresas. De acordo com Silveira (2011):

\begin{abstract}
Portanto, ativos e recursos não são alheios à relocalização de atividades no território. Dir-se-ia que as grandes empresas têm maior capacidade, graças à cognoscibilidade do planeta (Santos, 2000), de reconhecer tecnicamente recursos genéricos e específicos e de transformá-los em ativos ao seu favor. Evidente que tal transformação supõe um exercício político, tanto dentro da corporação como, sobretudo, fora dela, no âmbito do poder público. Daí que as grandes firmas, globais e nacionais, usem o território nacional segundo seu poder e as aptidões "naturais" e artificiais dos lugares, liderando o processo de dispersão das indústrias dinâmicas, da agricultura moderna em áreas novas e do respectivo setor de serviços (SILVEIRA, 2011, p. 5).
\end{abstract}

Nesse contexto, é muito comum a ocorrência da especialização regional produtiva (SCOTT e STORPER, 2003; SILVEIRA, 2010; KEMENY e STORPER, 2014), processo que pode ser entendido como a (re)configuração de uma região e de seus respectivos recursos naturais, geoeconômicas e político-normativo-institucionais ao serviço da produção e da circulação eficiente de uma ou mais atividades ou setores econômicos hegemônicos, isto é, para a consecução flexível e especializada, muitas vezes de forma competitiva, de um determinado bem ou serviço. Isto porque segundo Santos (2000, p. 81), "todo e qualquer pedaço da superfície da Terra se torna funcional às necessidades, usos e apetites de Estados e empresas nesta fase da história", e "os lugares se especializam, em função de suas virtualidades naturais, de sua realidade técnica e de suas vantagens de ordem social. Isso responde à exigência de maior segurança e rentabilidade para capitais obrigados a uma competitividade sempre crescente" (SANTOS, 1996, p. 146).

Esse processo também se relaciona à (re) qualificação técnica e política dos lugares aos preceitos do neoliberalismo econômico (HARVEY, 2005) ao qual as grandes corporações e o sistema financeiro mundializado estão imbricados (CHESNAIS, 2005), evidenciando o que muitos interpretam por competitividade regional (BUDD e HIRMIS, 2004; KITSON et al., 2004; BOSCHMA, 2004; BRISTOW,

Caminhos de Geografia Uberlândia $\quad$ v. 20, n. $72 \quad$ Dez/2019 $\quad$ p. 169-188 Página 171


2005; 2010a). Porém, por se tratar de regiões que geralmente são condicionadas a uma lógica de especialização produtiva e de intensa subordinação aos mercados internacionais (que é recorrentemente instável), um quadro de vulnerabilidade territorial se estabelece (ARROYO, 2006), ligado ao constante risco local em relação às implicações sociais, econômicas e ambientais provocadas por eventuais crises do sistema e pelo uso privativo e descompromissado do território (SANTOS e SILVEIRA, 2001).

Uma das atividades econômicas que tem sido responsável pela ocorrência da especialização regional produtiva é o agronegócio globalizado (CASTILLO, 2011; FREDERICO, 2013; ELIAS, 2017). Sendo basicamente operado por transnacionais e investidores financeiros de alcance global, através de técnicas e informações cada vez mais sofisticadas (SANTOS, 2000), se realiza a partir de um uso estritamente corporativo e seletivo dos territórios nacionais. A expansão da produção em larga escala mediante regime de monoculturas (grãos, café, cana-de-açúcar, algodão, silvicultura, pastagens para bovinos etc.), por exemplo, significa tornar o espaço produtivo altamente especializado na consecução de poucas atividades ou produtos, reduzindo consideravelmente a diversificação regional produtiva. Para Elias (2013), as principais áreas da produção agropecuária moderna no Brasil podem ser consideradas Regiões Produtivas do Agronegócio (RPAs), aonde ocorrem intensas transformações geográficas tanto no campo quanto nas cidades para atender eficientemente as grandes corporações do ramo. Já Castillo; Frederico (2010a) propõem reconhecer essas áreas com grande desempenho competitivo (qualidade e custos) como regiões competitivas agrícolas e/ou agroindustriais, possuidoras de alta concentração de fatores técnico-científico e organizacionais extremamente funcionais ao agronegócio globalizado.

No caso do setor sucroenergético, observa-se que sua dinâmica de espacialização ocasiona um intenso processo de especialização produtiva nas regiões em que as UAS se instalam. De acordo com Castillo (2013; 2015), devido à algumas características intrínsecas do setor sucroenergético, como a restrição ao armazenamento da matéria-prima (perecebilidade em até $48 \mathrm{~h}$, dificultando a localização de cultivos em áreas distantes do centro de moagem) e o ciclo econômico vegetativo (rendimento médio agrícola viável até o $5^{\circ}$ corte, necessitando do equilíbrio entre áreas de reforma, cana recém plantada, cana de primeiro corte e cana soca para demais cortes), as lavouras canavieiras precisam obrigatoriamente estar localizadas próximas às unidades de processamento. Desta forma, é fundamental que haja a implantação de uma extensa monocultura às adjacências das UAS, bem como a constituição de infraestruturas e serviços urbanos especializados para atender à produção e à logística da matéria-prima e de seus derivados industriais (etanol, açúcar e bioeletricidade). Tal situação inibe o compartilhamento das terras com outras atividades agrícolas e/ou pecuárias e causa forte dependência, sobretudo de pequenas cidades, à dinâmica da produção agroindustrial sucroenergética. Para Castillo (2013; 2015), o padrão de ocupação do agronegócio canavieiro promove a exacerbação da especialização regional (e territorial) produtiva, visto que esta atividade resulta em maior "rigidez" e "engessamento" do uso do solo rural e das atividades urbanas, isto é, do território.

O cálculo da participação da área cultivada de cana-de-açúcar na área total dos municípios é um exemplo claro do uso engessado do território pela agroindústria sucroenergética. O mapa da Figura 1 mostra as porções da região Centro-Sul com maior densidade de cultivo canavieiro, evidenciando as áreas de forte especialização regional produtiva agrícola. Percebemos que os municípios com maior taxa de ocupação de cana ( $61 \%$ a $82 \%$ da área total do município) se encontram sobretudo no nordeste do estado de São Paulo. Todavia, outras áreas de grande presença de UAS (Norte Paranaense, Triângulo Mineiro e Noroeste de Minas, Sul e Sudoeste Goiano, Sul de Mato Grosso do Sul) também possuem taxas relevantes de ocupação municipal (de $21 \%$ a $60 \%$ ) (apesar do tamanho maior dos municípios dessas regiões influenciar em menores taxas, mesmo com extensa área cultivada) o que demonstra grande percentual do uso das terras pelo setor sucroenergético em suas principais regiões produtivas.

Caminhos de Geografia Uberlândia $\quad$ v. 20, n. $72 \quad$ Dez/2019 $\quad$ p. 169-188 Página 172


Figura 1 - Região Centro-Sul: taxa de ocupação municipal de cana-de-açúcar, safra 2017/2018.

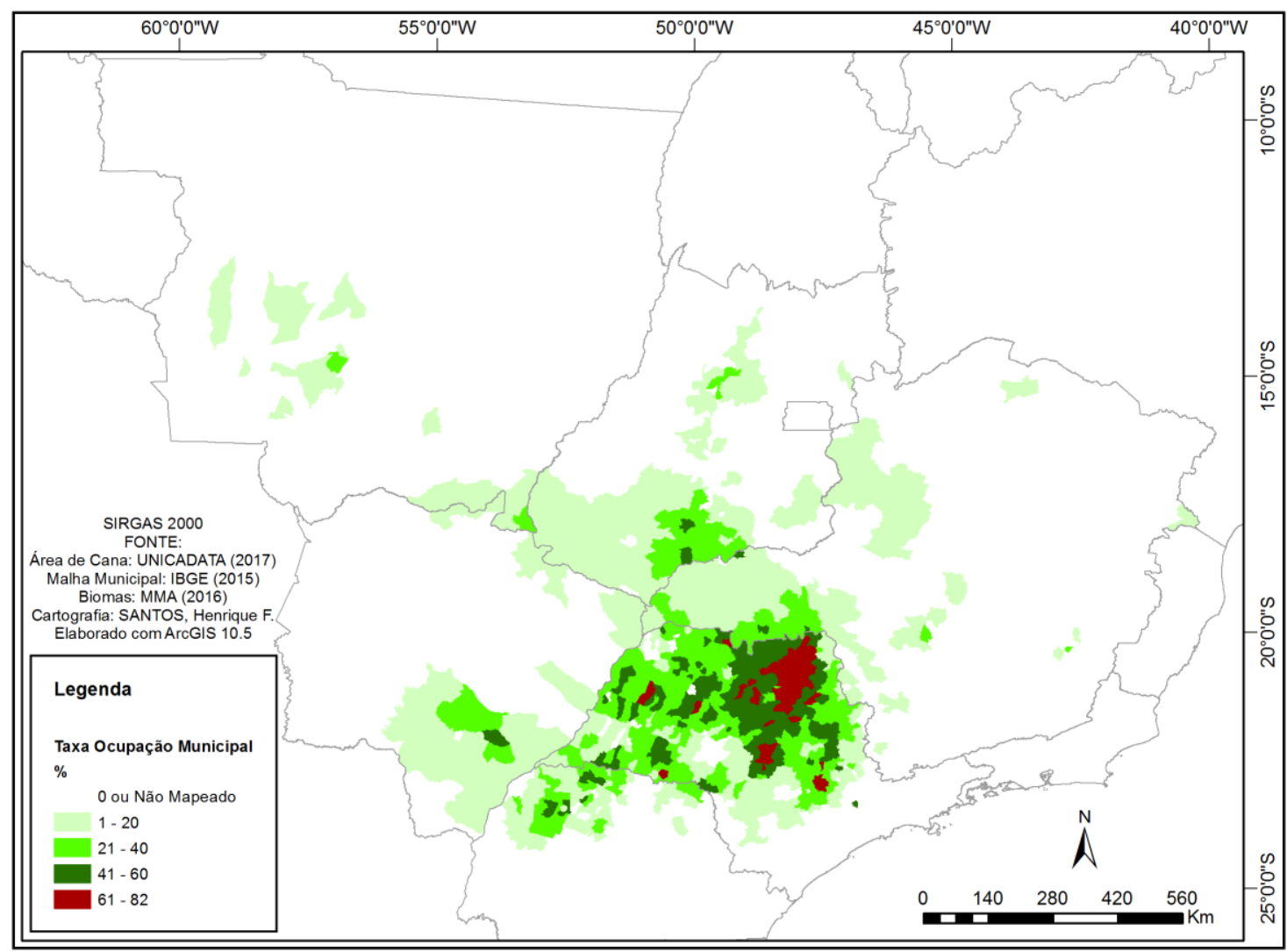

Fonte - UNICA (2018). Cartografia: SANTOS, Henrique.

Contudo, a alta especialização territorial produtiva (SILVEIRA, 2011) dos municípios sucroenergéticos, que compreendemos ser aqueles com área agropecuária ocupada expressivamente por cana-de-açúcar e/ou que possua UAS instalada, pode levar a um quadro preocupante de vulnerabilidade territorial (CAMELINI e CASTILLO, 2012). Pereira (2015) e Stacciarini e Pereira (2018), por exemplo, têm denominado alguns pequenos núcleos urbanos do Triângulo Mineiro, notadamente ritmados pelo setor sucroenergético, de "cidades da cana", que apresentam muitas implicações socioeconômicas e ambientais decorrentes da forte especialização produtiva local. No geral, segundo Pereira (2015), essas cidades possuem as seguintes características:

1) São pequenos núcleos urbanos, em geral pouco populosos (no caso do Triângulo Mineiro variando entre 04 e 18 mil habitantes), que possuem uma ou mais usinas sucroenergéticas em área territorial municipal (com usinas próximas ou não da área urbana); 2) Tais núcleos estão inseridos em municípios com amplo predomínio da cultura da cana em sua área territorial, quando comparada ao conjunto dos outros cultivos agrícolas (tanto os temporários quanto os permanentes), gerando paisagens monótonas que na última década ganham espaço no Triângulo Mineiro; e 3) Na maioria dos casos, tais núcleos possuem economia predominantemente pautada na atividade agropecuária (setor primário) ou industrial (um setor secundário resultante no mais das vezes exclusiva ou significativamente das atividades sucroenergéticas).

Sendo assim, é emblemático que em casos de fechamento temporário ou definitivo de UAS ocorra diversos impactos negativos nesses lugares, como a contração da produção agrícola, o fechamento de empresas (indústria e serviços), a redução dos postos de trabalho, a diminuição da renda dos habitantes, o colapso do comércio local, queda na arrecadação fiscal (quota parte municipal do ICMS, ISS), etc., estabelecendo-se um quadro de grande fragilidade, com perda inclusive da autonomia

$\begin{array}{lllll}\text { Caminhos de Geografia } & \text { Uberlândia } & \text { v. 20, n. } 72 & \text { Dez/2019 } & \text { p. 169-188 Página } 173\end{array}$


econômica local em decorrência dessa situação (CAMELINI e CASTILLO, 2012). Estes problemas têm sido muito comuns em diversos municípios afetados pela falência ou suspensão temporária de funcionamento de UAS (recuperação judicial), eventos que passaram a ser muito frequentes após a crise econômica e financeira internacional de 2007-2008 (HARVEY, 2011), que culminou em sérias dificuldades ao setor sucroenergético brasileiro (MENDONÇA et al., 2012) que duram até hoje (NOVACANA, 2019).

No entanto, é importante frisar que a vulnerabilidade territorial associada ao setor sucroenergético, conforme entendem Camelini e Castillo (2012), não significa apenas a fragilização econômica de um município provocada por eventual cessamento da atividade agroindustrial. Mas também se relaciona às diversas implicações socioambientais que a atividade causa aos municípios produtores durante a sua operação, sobretudo àqueles que tiverem forte expansão da monocultura canavieira. Dentre os problemas, destacam-se: desemprego no campo (monocultivo e mecanização agrícola, diminuição da diversidade produtiva rural), irregularidades trabalhistas (sobretudo nas grandes fazendas fornecedoras de cana-de-açúcar), controle e elevação do preço das terras (aquisição e arrendamento), expropriação camponesa, concentração fundiária, diminuição de outros cultivos alimentares, desmatamentos, contaminação atmosférica (pulverização aérea de defensivos químicos, queimadas ilegais), degradação dos solos e recursos hídricos, desequilíbrios ecológicos (fauna e flora), etc. (SZMRECSANYI e GONÇALVES, 2009; THOMAZ JUNIOR, 2009; CAMELINI e CASTILLO, 2012; PITTA et al., 2014; GAVIRA, 2015). Para Camelini (2011), a vulnerabilidade territorial associada ao setor sucroenergético pode ser entendida como:

[...] a fragilização espacial decorrente da especialização para a produção de etanol [e açúcar] que, por um lado, confere atributos de competitividade diferenciados para este segmento específico de atuação enquanto, por outro, diminui a autonomia local, à medida que insere o município num contexto de produção global, dentro do qual ele se torna extremamente funcional e alienado. Como resultantes deste processo, podem ser observadas diversas manifestações potencialmente comprometedoras da qualidade de vida, que decorrem da interferência direta ou indireta de agentes e processos totalmente desvinculados da realidade local (CAMELINI, 2011, p. 58).

Nesse sentido, procuramos investigar essa problemática a partir de um estudo realizado na mesorregião Triângulo Mineiro/Alto Paranaíba, que passou por vigorosa expansão do setor sucroenergético até 2011 (PEREIRA, 2012; REIS, 2013; PETRONZIO, 2014; SANTOS, 2017) e, posteriormente, contou com a falência de algumas UAS. Muitos municípios que receberam investimentos de grupos nacionais e transnacionais para instalação de UAS e cultivo de cana-deaçúcar tiveram enormes transformações espaciais associadas as mudanças de uso e ocupação do solo rural e à forte vinculação das atividades urbanas ao setor, representando uma especialização produtiva e suposta vulnerabilidade territorial.

\section{A EXPANSÃO DO SETOR SUCROENERGÉTICO NO TRIÂNGULO MINEIRO/ALTO PARANAíBA PÓS ANOS 2000}

Embora antes do presente século já houvesse 10 UAS instaladas e grandes áreas de cultivo de canade-açúcar no Triângulo Mineiro/Alto Paranaíba, foi sobretudo a partir do ano 2000 que a região vivenciou um novo período de expansão do setor sucroenergético, com a implantação de mais 15 UAS (Figura 2). Diferente do que vinha ocorrendo até então, cujos investimentos eram realizados principalmente por grupos de usineiros de capital nacional (maioria nordestinos), o período recente de crescimento da atividade sucroenergética está atrelada especialmente aos investimentos protagonizados por grupos transnacionais, como a Bunge, BP e Dow, na construção de unidades greenfields com enorme capacidade de produção (CAMPOS, 2019). Em decorrência disso, a área de lavoura canavieira cresceu extraordinariamente, conforme podemos ver no gráfico da Figura 3.

$\begin{array}{llllll}\text { Caminhos de Geografia } \quad \text { Uberlândia } & \text { v. 20, n. } 72 & \text { Dez/2019 } & \text { p. 169-188 Página } 174\end{array}$


Figura 2 - Triângulo Mineiro/Alto Paranaíba: evolução do número de UAS, 2000-2018.

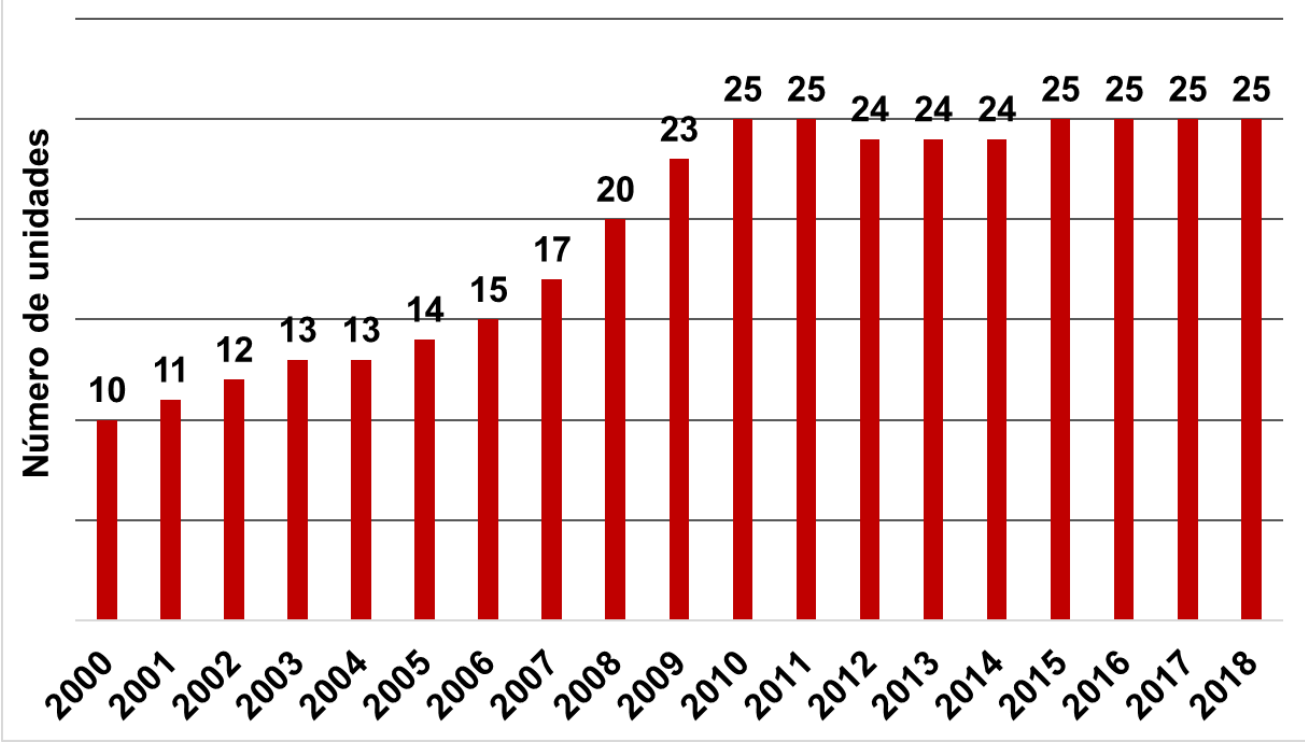

Fonte - Campos (2014), INFOCANA (2019), NovaCana (2019), websites das empresas.

Figura 3 - Triângulo Mineiro/Alto Paranaíba: evolução da área plantada das principais lavouras, 20002016.

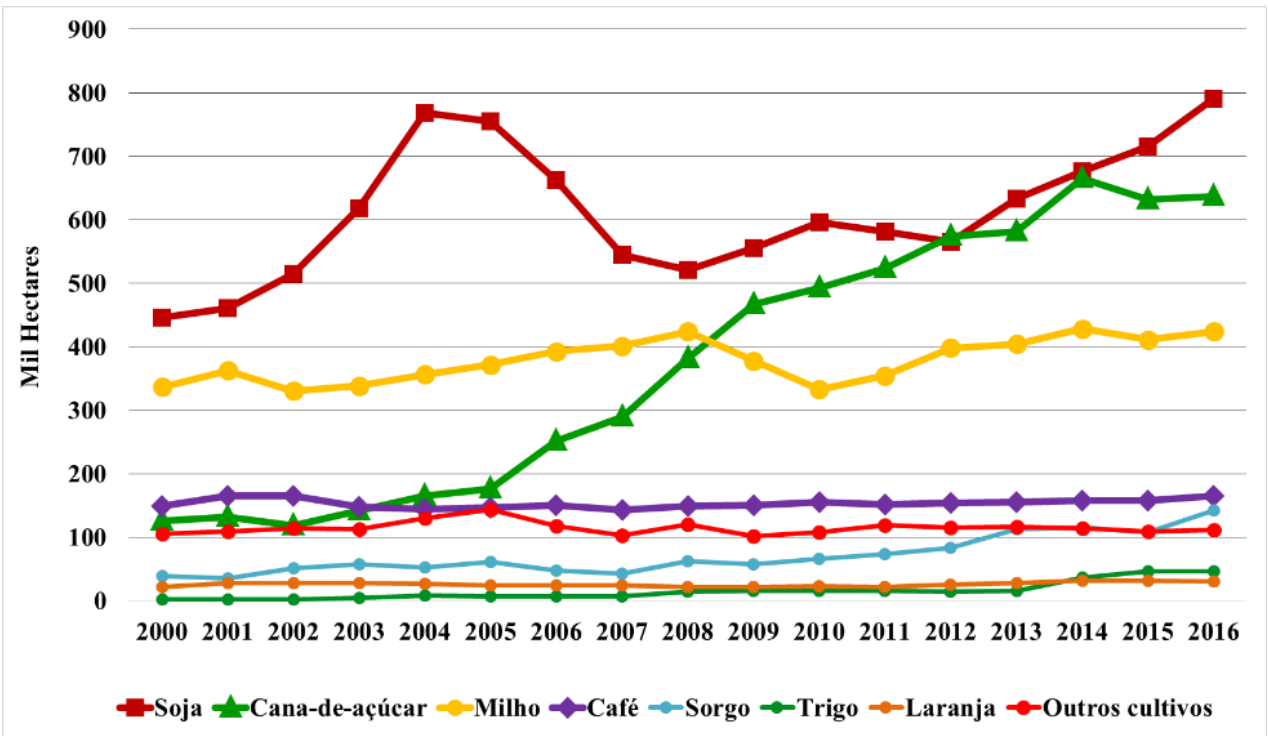

Fonte - Santos (2017, p. 90) a partir de Produção Agrícola Municipal - PAM (IBGE, 2017).

A área plantada com cana-de-açúcar aumentou quase 511 mil hectares no período de 2000 a 2016 (de 126,5 mil para 637,2 mil hectares), ou seja, um aumento de mais de $400 \%$. O aumento da quantidade produzida também foi expressivo, passando de 10 milhões de toneladas para 50,3 milhões no mesmo período, um aumento de 390\% (Tabela 1). Observa-se também um discreto aumento na produtividade da cana-de-açúcar na região. Conforme dados do PAM/IBGE, em 2001 o rendimento médio da cultura foi de 75,9 toneladas/hectare, aumentando gradualmente até 2009 , quando atingiu 87,9 toneladas/hectares. Depois houve sucessivas quedas, chegando a 79,2 toneladas/hectares em 2016 (Tabela 1). A despeito desta redução, o rendimento médio do último ano

$\begin{array}{llllll}\text { Caminhos de Geografia } & \text { Uberlândia } & \text { v. 20, n. } 72 & \text { Dez/2019 } & \text { p. 169-188 } & \text { Página } 175\end{array}$


ficou acima do obtido no estado de Minas Gerais (76,9 ton./ha), em São Paulo (79,1 ton./ha) e no Brasil (75,1 ton./ha) (PAM/IBGE, 2016).

Tabela 1 - Triângulo Mineiro/Alto Paranaíba: área plantada, quantidade produzida e rendimento médio da cana-de-açúcar, 2000, 2005, 2010 e 2016.

\begin{tabular}{c|c|c|c}
\hline Anos & $\begin{array}{c}\text { Área colhida } \\
\text { (hectares) }\end{array}$ & $\begin{array}{c}\text { Quantidade produzida } \\
\text { (toneladas) }\end{array}$ & $\begin{array}{c}\text { Rendimento médio } \\
\text { (ton./ha) }\end{array}$ \\
\hline 2000 & 126.500 & 10.076 .488 & 79,6 \\
2005 & 176.791 & 14.459 .650 & 81,7 \\
2010 & 492.440 & 42.415 .800 & 86,1 \\
2016 & 637.268 & 50.331 .762 & 79,2 \\
\hline
\end{tabular}

Fonte - Produção Agrícola Municipal - PAM (IBGE, 2018). Organização: SANTOS, Henrique.

Desse modo, a região conheceu uma grande ampliação geográfica do agronegócio sucroenergético, que transformou completamente a paisagem rural de vários municípios numa imensidão de canaviais. Em Uberaba/MG, maior produtor de cana-de-açúcar da mesorregião, por exemplo, a área plantada aumentou de 5 mil hectares em 2000 para 73,7 mil hectares em 2016. Em Frutal/MG, segundo maior produtor, a área plantada com cana-de-açúcar passou de 3,6 mil para 61,9 mil hectares. Em Santa Vitória/MG, terceiro maior produtor, a expansão foi de 40 hectares para 54 mil hectares. E em Campo Florido/MG, quinto maior produtor, a lavoura ampliou-se de 800 hectares para quase 32 mil hectares no mesmo período (Tabela 2).

Tabela 2 - Triângulo Mineiro/Alto Paranaíba: área plantada (hectares) de cana-de-açúcar nos dez maiores municípios sucroenergéticos, 2000, 2005, 2010 e 2016.

\begin{tabular}{lcccc}
\hline \multicolumn{1}{c}{ Municípios } & 2000 & 2005 & 2010 & 2016 \\
\hline Uberaba & 5.000 & 20.000 & 46.000 & 73.720 \\
Frutal & 3.600 & 8.228 & 30.689 & 61.972 \\
Santa Vitória & 40 & 5 & 25.867 & 54.000 \\
Conceição das Alagoas & 15.000 & 14.000 & 40.000 & 45.000 \\
Campo Florido & 800 & 12.600 & 17.500 & 31.844 \\
Iturama & 19.608 & 21.295 & 30.900 & 28.820 \\
Ituiutaba & 500 & 6.700 & 24.000 & 26.000 \\
Limeira do Oeste & 2.502 & 2.300 & 18.000 & 24.212 \\
Conquista & 11.000 & 7.500 & 15.000 & 21.200 \\
Água Comprida & 4.000 & 6.160 & 19.500 & 26.000 \\
\hline
\end{tabular}

Fonte - Produção Agrícola Municipal - PAM (IBGE, 2018). Organização: SANTOS, Henrique.

Os mapas das Figuras 4 e 5, produzidos a partir de dados do projeto Canasat (2016) e disponibilizados pela Agrosatélite Geotecnologia Aplicada (mediante solicitação), mostram com precisão as áreas da região que mais sofreram expansão do setor sucroenergético entre 2005 e 2016. Podemos ver que a instalação de novas UAS e a ampliação das lavouras se deram sobretudo nas porções sul, onde já ocorria uma significativa produção canavieira desde a década de 1980, e a porção norte e oeste, que se constituem nas novas fronteiras de expansão sucroenergética pós 2003. Nota-se que essas áreas são adjacentes aos grandes rios que delimitam a mesorregião, os rios Grande e Paranaíba, o que significa o aproveitamento estratégico dos recursos hídricos (afluentes e rios principais) para as operações agrícolas e agroindustriais, no sistema agrohidronegócio (THOMAZ JUNIOR, 2009).

Caminhos de Geografia Uberlândia $\quad$ v. 20, n. $72 \quad$ Dez/2019 $\quad$ p. 169-188 Página 176


Figura 4 - Triângulo Mineiro/Alto Paranaíba: espacialização da área cultivada com cana-de-açúcar e localização das UAS, 2005.

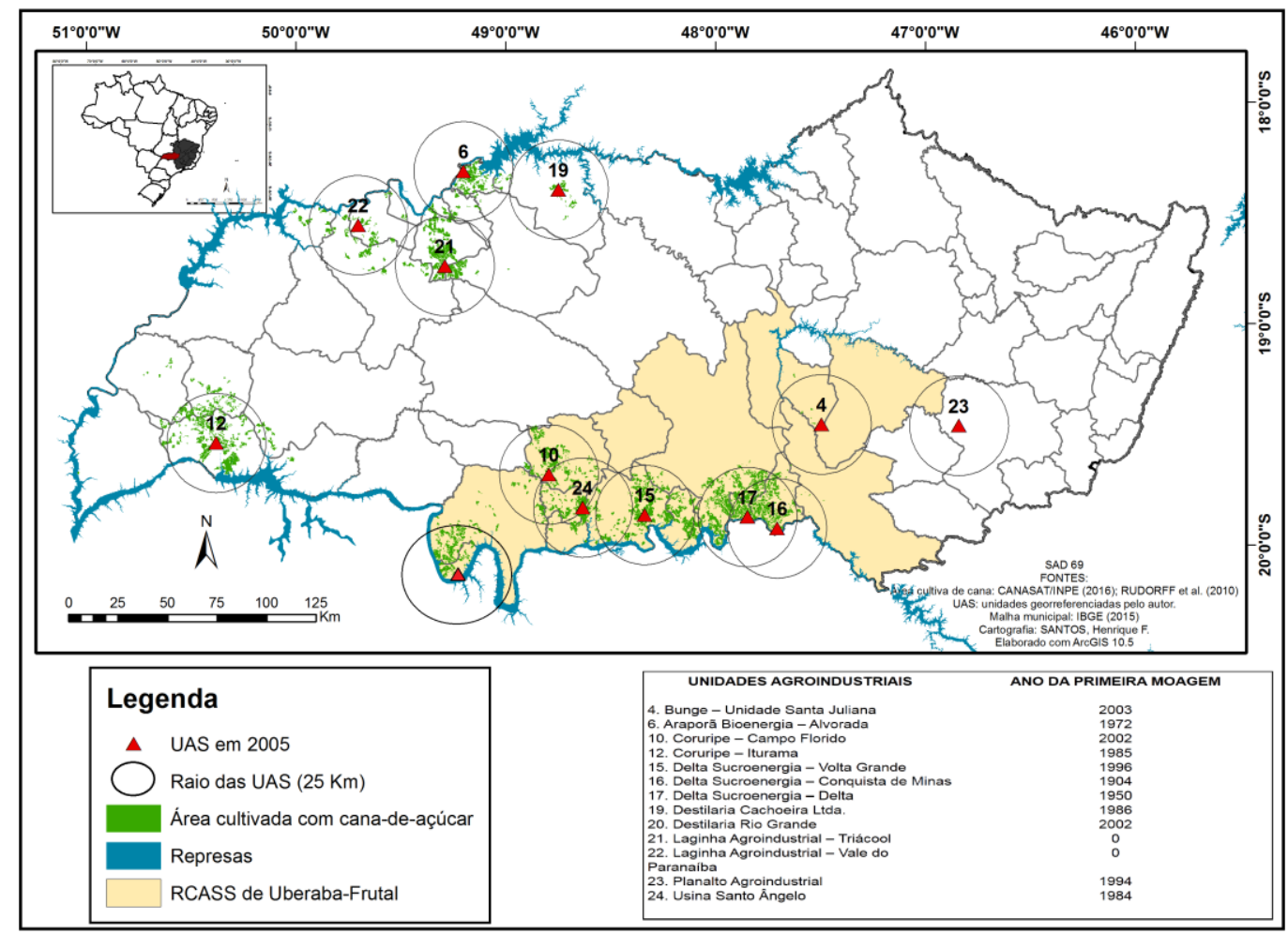

Fonte - Santos (2017a, p. 94) a partir de CANASAT/INPE (2016); Rudorff et al. (2010).

Figura 5 - Triângulo Mineiro/Alto Paranaíba: espacialização da área cultivada com cana-de-açúcar e localização das UAS, 2016.

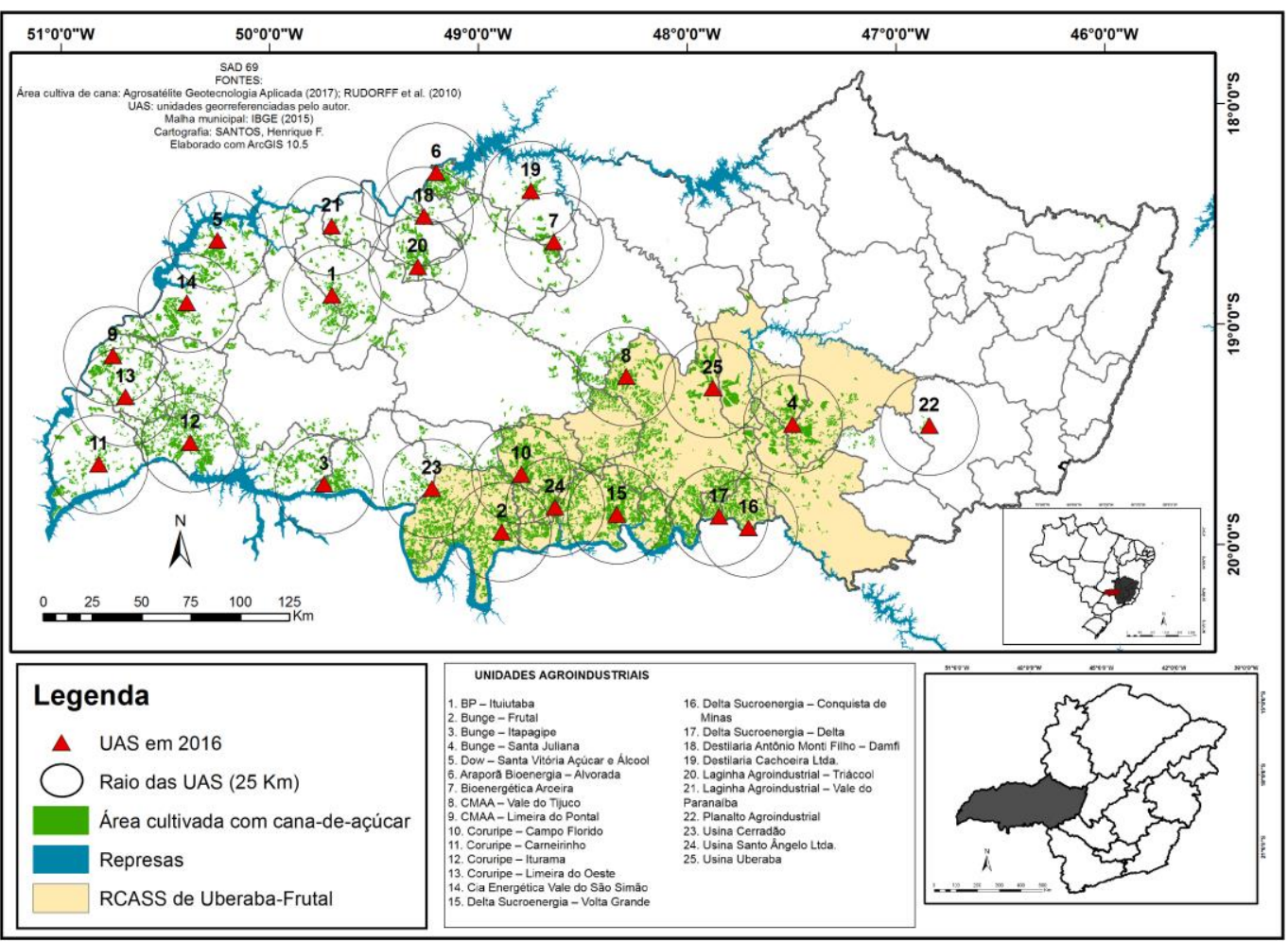

Fonte - Santos (2017a, p. 94) a partir de Agrosatélite Geotecnologia Aplicada (2017); Rudorff et al. (2010).

\begin{tabular}{lllll}
\hline Caminhos de Geografia $\quad$ Uberlândia & v. 20, n. 72 & Dez/2019 & p. 169-188 & Página 177
\end{tabular}


O crescimento do número de UAS e o controle dessas unidades por grandes corporações nacionais e transnacionais com elevada capacidade de realizar investimentos é o principal fator responsável pela expansão acelerada das áreas ocupadas por cana-de-açúcar. Para Pereira (2012), essa expansão ocorreu nas melhores áreas da região (sobretudo anteriormente ocupadas por grãos e pastagens) e com intenso uso de técnicas modernas de produção agrícola.

No que se refere à expansão territorial do cultivo, há claro esforço de ocupação, por parte dos novos grupos que investem na instalação de usinas, das áreas com melhor qualidade de solo e passíveis de mecanização (topografia plana). Isso tem ocorrido a partir da substituição de áreas antes ocupadas por cultivos temporários (inclusive com alguma competição em áreas antes cultivadas com milho/soja), mas principalmente pela substituição de áreas de pastagem. Intenso em técnica e envolvendo agentes qualificados para um trabalho diretamente ligado à ciência e tecnologia (emprego de defensivos, corretivos, máquinas modernas para a colheita, remuneração a partir de cálculo do teor de glicose nas plantas, etc.), o cultivo da cana de açúcar, da forma como tem atualmente se expandido na região, reforça o caráter da agricultura moderna e intensa em capital (PEREIRA, 2012, p. 96).

Portanto, a instalação de UAS se restringiu as áreas da mesorregião com melhores condições geográficas para retorno dos investimentos, visando a eficiência produtiva e logística e a propalada busca por competitividade (CASTILLO, 2015). Dentre os fatores primordiais de localização, estão aqueles relacionados ao caráter natural (condições edafoclimáticos favoráveis ao cultivo da cana, topografia plana, disponibilidade hídrica) e geoeconômico (disponibilidade de terras cultiváveis em larga extensão, infraestruturas logísticas, centros de PD\&l e formação de mão de obra qualificada, cidades funcionais ao campo moderno com serviços especializados à agricultura e à agroindústria) (SANTOS, 2017).

\section{A VULNERABILIDADE TERRITORIAL DOS MUNICÍPIOS SUCROENERGÉTICOS DO TRIÂNGULO MINEIRO/ALTO PARANAÍBA}

Embora a dinâmica de expansão sucroenergética tenha representado grandes somas de investimentos em infraestrutura, geração de empregos e renda, dinamizando várias economias locais, o processo como um todo provocou, além do aumento da especialização regional produtiva no Triângulo Mineiro/Alto Paranaíba (SANTOS, 2019), a exacerbada especialização territorial produtiva (SILVEIRA, 2011) de vários municípios produtores e/ou processadores de cana-de-açúcar. O conjunto de alguns desses municípios forma sub-regiões que tiveram nos últimos anos uma diminuição drástica de outros cultivos em detrimento da cana-de-açúcar (SANTOS, 2017), além da refuncionalização de núcleos urbanos para atender as demandas de infraestruturas e serviços que UAS e seus fornecedores necessitam, como ocorreu na área denominada "Pontal do Triângulo Mineiro" e em vários municípios da porção sul da mesorregião.

A partir da análise de alguns indicadores, verifica-se que muitos desses municípios apresentam uma alta dependência econômica ao setor sucroenergético, pois se trata de municípios com baixo patamar demográfico (representando pequenos núcleos urbanos, para o padrão brasileiro) e com grande nível de especialização produtiva, tanto no campo quanto na cidade. A Tabela 4 exibe os principais municípios sucroenergéticos do Triângulo Mineiro/Alto Paranaíba com alguns indicadores de especialização territorial produtiva. Já o mapa da Figura 6 representa a taxa de ocupação municipal da cana-de-açúcar no total de lavouras temporárias e permanentes em 2016 e a localização das UAS. Dos 66 municípios da mesorregião, consideramos metade deles como municípios sucroenergéticos, enquadrados em uma das seguintes situações: 1) municípios com UAS instaladas em seu território e com expressiva área de cana-de-açúcar; 2) municípios com UAS instaladas e com

$\begin{array}{lllll}\text { Caminhos de Geografia } & \text { Uberlândia } & \text { v. 20, n. } 72 & \text { Dez/2019 } & \text { p. 169-188 Página } 178\end{array}$


pouca área de cana-de-açúcar; 3) municípios sem UAS instaladas e com expressiva área de cana-deaçúcar (acima de 1.000 ha).

A Tabela 3 mostra o conjunto de municípios que tiveram grande crescimento da área plantada e da participação da cana-de-açúcar na área total de lavouras temporárias e permanentes entre 2000 e 2016, evidenciando uma forte especialização da produção agrícola local.

Tabela 3 - Triângulo Mineiro/Alto Paranaíba: área plantada e participação (\%) da cana-de-açúcar na área total de lavouras temporárias e permanentes em alguns municípios sucroenergéticos, 2000, 2004, 2008, 2012 e 2016.

\begin{tabular}{|c|c|c|c|c|c|c|c|c|c|c|}
\hline \multirow[b]{2}{*}{ Municípios } & \multicolumn{2}{|c|}{2000} & \multicolumn{2}{|c|}{2004} & \multicolumn{2}{|c|}{2008} & \multicolumn{2}{|c|}{2012} & \multicolumn{2}{|c|}{2016} \\
\hline & Área & $\%$ & Área & $\%$ & Área & $\%$ & Área & $\%$ & Área & $\%$ \\
\hline Áqua Comprida & 4.000 & 22.3 & 8.985 & 35,0 & 10.000 & 48.9 & 19.000 & 64.4 & 26.000 & 62.9 \\
\hline Arap & 6.300 & 56,9 & 5.980 & 58,5 & 7.680 & 63,4 & 10.959 & 87,5 & 9.019 & 86,9 \\
\hline o Florido & 800 & 2,0 & 12.107 & 25,0 & 18.000 & 42,5 & 20.000 & 50,4 & 26.000 & 47,8 \\
\hline & 470 & 11,3 & 200 & 7,4 & 900 & 85,8 & 6.000 & 92,2 & 11.930 & 95,9 \\
\hline Co & 15.000 & 21,0 & 15.308 & 22,4 & 41.500 & 47,1 & 40.000 & 46,7 & 45.000 & 45,7 \\
\hline Conc & 11.000 & 39,9 & 6.163 & 23,2 & 12.000 & 54,0 & 15.000 & 47,3 & 21.200 & 53,3 \\
\hline Delta & 6.500 & 84,0 & 3.204 & 66,3 & 6.000 & 79,8 & 4.000 & 73,0 & 5.297 & 97,3 \\
\hline Frutal & 3.600 & 10,6 & 7.028 & 13,2 & 30.689 & 55,4 & 49.000 & 63,4 & 61.972 & 69,5 \\
\hline Itapa & 800 & 10,0 & 0 & 0,0 & 484 & 8,4 & 16.000 & 85,6 & 15.952 & 86,6 \\
\hline Itura & 19.608 & 84,9 & 21.295 & 84,8 & 21.500 & 95,5 & 30.500 & 97,2 & 28.820 & 95,9 \\
\hline Oeste & 2.502 & 36,4 & 2.392 & 33,2 & 12.000 & 95,5 & 18.800 & 95,3 & 24.212 & 93,3 \\
\hline & 6.280 & 31,2 & 4.400 & 21,7 & 14.000 & 59,2 & 14.000 & 59,6 & 12.970 & 47,2 \\
\hline Santa Vitória & 40 & 1,0 & 5 & 0,0 & 6.200 & 85,8 & 28.400 & 93,3 & 54.000 & 94,8 \\
\hline
\end{tabular}

Fonte - Produção Agrícola Municipal - PAM (IBGE, 2018). Organização: SANTOS, Henrique.

A taxa de ocupação da cana-de-açúcar no total das lavouras temporárias e permanentes, por exemplo, ficou acima de $40 \%$ nos municípios de Campina Verde (45\%), Conceição das Alagoas $(45 \%)$, Ituiutaba $(46 \%)$, Campo Florido $(47 \%)$, Pirajuba $(47 \%)$, Veríssimo $(48 \%)$, Ċonquista $(53 \%)$, Água Comprida $(62 \%)$, Frutal $(69 \%)$, Fronteira $(82 \%)$, União de Minas $(82 \%)$, Araporã $(86 \%)$, Itapagipe (86\%), Gurinhatã (91\%), Limeira do Oeste (93\%), Santa Vitória (94\%), São Francisco de Sales $(94 \%)$, Carneirinho (95\%), Iturama (95\%) e Delta $(97 \%)$. Nota-se que todos eles possuem UAS instaladas, demonstrando, portanto, a grande contribuição dessas unidades agroindustriais no engessamento do uso e ocupação do solo rural.

Alguns desses municípios, mais Uberaba, também tiveram uma taxa de ocupação da área total do território com cana-de-açúcar superior a $20 \%$ na safra 2017/2018: Fronteira $(21 \%)$, Uberaba $(21 \%)$, Limeira do Oeste $(23 \%)$, Iturama $(27 \%)$, Frutal $(30 \%)$, Conquista $(30 \%)$, Planura $(31 \%)$, Campo Florido (33\%), Conceição das Alagoas (36\%), Água Comprida (37\%), Araporã (41\%), Pirajuba $(43 \%)$, Delta $(47 \%)$. Tal indicador sugere que considerando as pastagens e outras formas de uso do solo rural (já que no período em que foi realizada a pesquisa não havia dados atualizados sobre área de pastagens e de vegetação nativa, sendo o último do Censo Agropecuário de 2006), há uma iminente especialização do campo para a produção de cana-de-açúcar. Isso é mais evidente quando analisamos a participação da cana-de-açúcar no valor total da produção das lavouras (R\$), que esteve acima de $50 \%$ em todos os municípios citados (exceto Uberaba, com $34,3 \%$ ), e a participação da cana-de-acúcar no total do crédito rural de custeio (R\$), que foi superior a $50 \%$, por exemplo, em Tupaciguara (51\%), Pirajuba (53\%), Campo Florido (66\%), Araporã (80\%) e Delta (82\%) (Tabela 4).

Indicadores como a participação do setor sucroenergético na arrecadação fiscal, nas exportações e no mercado formal de trabalho são ainda mais contundentes. De acordo com os dados da Secretaria de Estado de Fazenda de Minas Gerais (SEFAZ-MG, 2016), o setor foi responsável por mais de 40\% da arrecadação fiscal dos municípios de Carneirinho (42\%), Itapagipe (43\%), Tupaciguara (52\%), Santa Juliana $(54 \%)$, Campo Florido (59\%), Água Comprida $(63 \%)$, Limeira do Oeste $(71 \%)$, Delta $(80 \%)$, Conceição das Alagoas (84\%) e Pirajuba (86\%), todos com UAS instaladas (exceto Água Comprida). Uma das razões é a grande participação do setor na pauta exportadora, que passou de $40 \%$ em todos eles (exceto Água Comprida, que não tem UAS), além de Uberaba (45\%), Frutal $(51 \%)$ e Iturama (79\%), que também possuem UAS. Em relação ao total de empregos formais, o setor tem forte participação em Tupaciguara (20\%), Iturama (28\%), Campo Florido $(33 \%)$, Santa Juliana $(33 \%)$, Conquista $(36 \%)$, Itapagipe (36\%), Conceição das Alagoas (38\%), Santa Vitória (42\%), Limeira do Oeste (52\%), Delta (63\%) e Pirajuba (75\%) (Tabela 4).

$\begin{array}{llllll}\text { Caminhos de Geografia } \quad \text { Uberlândia } & \text { v. 20, n. } 72 & \text { Dez/2019 } & \text { p. 169-188 } & \text { Página } 179\end{array}$


Tabela 4 - Triângulo Mineiro/Alto Paranaíba: indicadores de especialização territorial produtiva dos municípios sucroenergéticos, $2016-2017$.

\begin{tabular}{|c|c|c|c|c|c|c|c|c|c|c|c|c|}
\hline \multirow[b]{2}{*}{ Municípios } & \multicolumn{4}{|c|}{ Dados do Setor Sucroenergético } & \multicolumn{7}{|c|}{ Participação da cana-de-açúcar ou setor sucroenergético (\%) } & \multirow[b]{2}{*}{ Grau de VT* } \\
\hline & $\begin{array}{l}\text { Habitantes } \\
\text { (estimativa de } \\
\text { 2017) (1) }\end{array}$ & $\begin{array}{l}\text { Área } \\
\text { plantada } \\
\text { de cana } \\
2016 \text { (2) }\end{array}$ & $\begin{array}{c}\text { Número de } \\
\text { UAS (3) }\end{array}$ & $\begin{array}{l}\text { Capacidade de } \\
\text { moagem } \\
2015 / 2016 \\
\text { (milhões } \\
\text { ton./safra) } \\
{ }^{(3)}\end{array}$ & $\begin{array}{l}\text { Área de } \\
\text { lavouras } \\
2016^{(2)}\end{array}$ & $\begin{array}{c}\text { Área do município } \\
\text { safra } 2017 / 2018 \\
(4)\end{array}$ & $\begin{array}{c}\text { Valor da } \\
\text { produção das } \\
\text { lavouras } 2016 \text { (2) }\end{array}$ & $\begin{array}{l}\text { Crédito } \\
\text { rural de } \\
\text { custeio } \\
2017 \text { (5) }\end{array}$ & $\begin{array}{l}\text { Valor das } \\
\text { exportaçōes } \\
2017 \text { (6) }\end{array}$ & $\begin{array}{l}\text { Arrecadação } \\
\text { fiscal } 2017 \text { (7) }\end{array}$ & $\begin{array}{c}\text { Empregos } \\
\text { formais } 2016 \\
(8)\end{array}$ & \\
\hline Água Comprida & 2.058 & 26.000 & 0 & 0 & 62,9 & 37,6 & 73,1 & 18,8 & 0,0 & 63,6 & 3,0 & Médio \\
\hline Araporã & 6.774 & 9.019 & 1 & 2,7 & 86,9 & 41,1 & 87,8 & 80,8 & 100,0 & 9,6 & 13,3 & Alto \\
\hline Campina Verde & 20.079 & 9.600 & 0 & 0 & 45,4 & 2,6 & 56,7 & 10,6 & 0,0 & 0,0 & 0,3 & Baixo \\
\hline Campo Florido & 7.886 & 26.000 & 1 & 3,8 & 47,8 & 32,2 & 60,2 & 66,0 & 91,1 & 59,1 & 33,7 & Muito Alto \\
\hline Canápolis & 10.151 & 10.000 & 1 & & 38,3 & 14,3 & 30,9 & 1,6 & 0,0 & 11,7 & 8,0 & Baixo \\
\hline Carneirinho & 10.072 & 11.930 & 1 & 2,3 & 95,9 & 9,1 & 96,8 & 12,7 & 100,0 & 42,5 & 19,9 & Muito Alto \\
\hline Centralina & 10.622 & 6.000 & 0 & 0 & 21,2 & 11,2 & 30,6 & 1,4 & 0,0 & 0,0 & 3,9 & Baixo \\
\hline Comendador Gomes & 3.138 & 5.899 & 0 & 0 & 31,5 & 8,3 & 20,9 & 19,7 & 0,0 & 0,0 & 0,4 & Baixo \\
\hline Conceicão das Alagoas & 26.818 & 45.000 & 1 & 4,5 & 45,7 & 36,4 & 60,3 & 28,0 & 93,5 & 84,0 & 38,1 & Muito Alto \\
\hline $\begin{array}{l}\text { Conquista } \\
\text { als miads }\end{array}$ & 6.960 & 21.200 & 1 & $\begin{array}{c}4,0 \\
1\end{array}$ & 53,3 & 29,9 & 67,0 & 42,4 & 0,0 & $\begin{array}{l}4,0,3 \\
16,3\end{array}$ & 36,9 & Alto \\
\hline Delta & 9.904 & 5.297 & 1 & 4,3 & 97,3 & 47,5 & 98,8 & 82,1 & 96,9 & 80,8 & 63,2 & Muito Alto \\
\hline Fronteira & 17.072 & 3.682 & 0 & 0 & 82,7 & 21,3 & 48,8 & 27,0 & 0,0 & 0,0 & 0,8 & Médio \\
\hline Frutal & 58.770 & 61.972 & 2 & 4 & 69,5 & 30,9 & 56,6 & 33,7 & 51,2 & 28,7 & 18,5 & Médio \\
\hline Gurinhatã & 5.959 & 8.600 & 0 & 0 & 91,5 & $\begin{array}{l}30,5 \\
6,7\end{array}$ & 87,1 & $\begin{array}{l}30,1 \\
0,0\end{array}$ & $\begin{array}{c}0,0 \\
0,0\end{array}$ & $\begin{array}{c}20, r \\
0,0\end{array}$ & 0,0 & Baixo \\
\hline Ipiaçu & 4.285 & 4.600 & 0 & 0 & 23,4 & 8,6 & 40,5 & 3,0 & 0,0 & 0,0 & 0,0 & Baixo \\
\hline Itapagipe & 15.041 & 15.952 & 1 & 2 & 86,6 & 12,6 & 76,9 & 18,3 & 44,5 & 43,0 & 36,0 & Alto \\
\hline Ituiutaba & 104.526 & 26.000 & 1 & 2,2 & 46,3 & 9,4 & 59,5 & 3,7 & 18,4 & 3,8 & 10,2 & Baixo \\
\hline Iturama & 38.484 & 28.820 & 1 & 3,7 & 95 & $\begin{array}{l}26,9 \\
26,9\end{array}$ & 93,5 & $\begin{array}{l}54,4 \\
54,4\end{array}$ & $\begin{array}{l}10,4 \\
79,5\end{array}$ & $\begin{array}{l}0,0 \\
11,7\end{array}$ & 28,8 & Muito Alto \\
\hline Limeira do Oeste & 7.487 & 24.212 & 2 & 3 & 93,3 & 23,7 & 93,5 & 50,1 & 100,0 & 71,4 & 52,7 & Muito Alto \\
\hline Monte Alegre de Minas & 21.095 & 8.000 & 0 & 0 & 11,5 & 5,8 & 13,3 & 13,4 & 0,0 & 0,0 & 1,5 & Baixo \\
\hline Nova Ponte & 14.934 & 7.500 & 0 & 0 & 14,2 & 9,2 & 19,4 & 9,1 & 0.0 & 0.0 & 0,7 & Baixo \\
\hline Perdizes & 15.925 & 16.360 & 0 & 0 & $\begin{array}{l}14,2 \\
17,9\end{array}$ & $\begin{array}{l},, 2 \\
8,4\end{array}$ & $\begin{array}{l}9,4 \\
9,4\end{array}$ & 1,5 & 0,0 & 0,0 & 0,2 & Baixo \\
\hline Pirajuba & 5.790 & 12.970 & 1 & 3.1 & 47,2 & 43,2 & 60.9 & 53.7 & 100.0 & 86,8 & 75,7 & Muito Alto \\
\hline $\begin{array}{l}\text { Planura } \\
\text { Plana }\end{array}$ & 11.796 & 8.484 & 0 & $\begin{array}{c}0,1 \\
0\end{array}$ & 37,1 & 31,8 & 46,2 & 7,8 & 0,0 & $\begin{array}{c}00,0 \\
0,0\end{array}$ & $\begin{array}{l}5,1 \\
5,2\end{array}$ & Médio \\
\hline Prata & 27.796 & 8.594 & 0 & 0 & 21,6 & 2,8 & 20,5 & 9,3 & 0,0 & 0,0 & 0,2 & Baixo \\
\hline Sacramento & 25.998 & $\begin{array}{l}0.054 \\
16.260\end{array}$ & 0 & 0 & 18,8 & 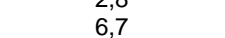 & 16,6 & $\begin{array}{l}, 0,0 \\
13,6\end{array}$ & 0,0 & 0,0 & 0,3 & Baixo \\
\hline Santa Juliana & 13.380 & 11.000 & 1 & 4 & 29,9 & 16.3 & 24,0 & 5,2 & 100,0 & 54.4 & 33,0 & Muito Alto \\
\hline Santa Vitória & 19.646 & 54.000 & 2 & 3,5 & 94,8 & $\begin{array}{l}10,0 \\
17,3\end{array}$ & 96,0 & 6,1 & 0,0 & 36,1 & 42,4 & Alto \\
\hline São Francisco de Sales & 6.224 & 14.330 & 0 & 0 & 94,9 & 15,9 & 73,2 & 14.1 & 0,0 & 1.1 & 14 & Baixo \\
\hline Tupaciguara & 25.538 & 11.379 & 2 & 1,3 & 19,6 & 7,1 & 32,0 & 51,7 & 96,9 & 52,6 & 20,3 & Muito Alto \\
\hline Uberaba & 328.272 & 73.720 & 2 & 6 & 25,9 & 21,7 & 34,3 & 35,0 & 45,2 & 1,0 & 2,9 & Baixo \\
\hline União de Minas & 4.452 & 14.980 & 0 & 0 & 82,6 & 16,0 & 88,3 & 24,2 & 0,0 & 0,0 & 14,7 & Alto \\
\hline Veríssimo & 3.911 & 11.500 & 0 & 0 & 48,0 & 20,6 & 58,6 & 36,4 & 0,0 & 0,6 & 4,3 & Médio \\
\hline
\end{tabular}

*VT - Vulnerabilidade Territorial (classificação feita, a priori, a partir da combinação dos indicadores apresentados, levando em consideração que quanto menor for o patamar demográfico do município e maiores os níveis de especialização em cada indicador, bem como a presença de UAS, mais alto é o VT).

Fontes - (1) IBGE Cidades (2018); (2) PAM/IBGE (2018); (3) PROCANA (2016), INFOCANA (2018) e NOVACANA (2018); (4) UNICA (2018) e IBGE (2018); (5)

BCB (2018); (6) MDIC (2018) conforme códigos do SECEX: 1701 (açúcar e sacarose), 2207 (etanol com volume igual ou superior a 80\% de teor alcoólico) e 2208

(etanol com volume inferior a 80\% de teor alcóolico); (7) SEFAZ-MG (2018) e (8) RAIS/MTE (2018) conforme códigos do CNAE: 011300 (cultivo de cana-deaçúcar), 107160 (fabricação de açúcar em bruto), 107240 (fabricação de açúcar refinado) e 193140 (fabricação de álcool).

Organização: SANTOS, Henrique. 
Figura 6 - Triângulo Mineiro/Alto Paranaíba: taxa de ocupação municipal da cana-de-açúcar no total de lavouras e localização das UAS, 2016.

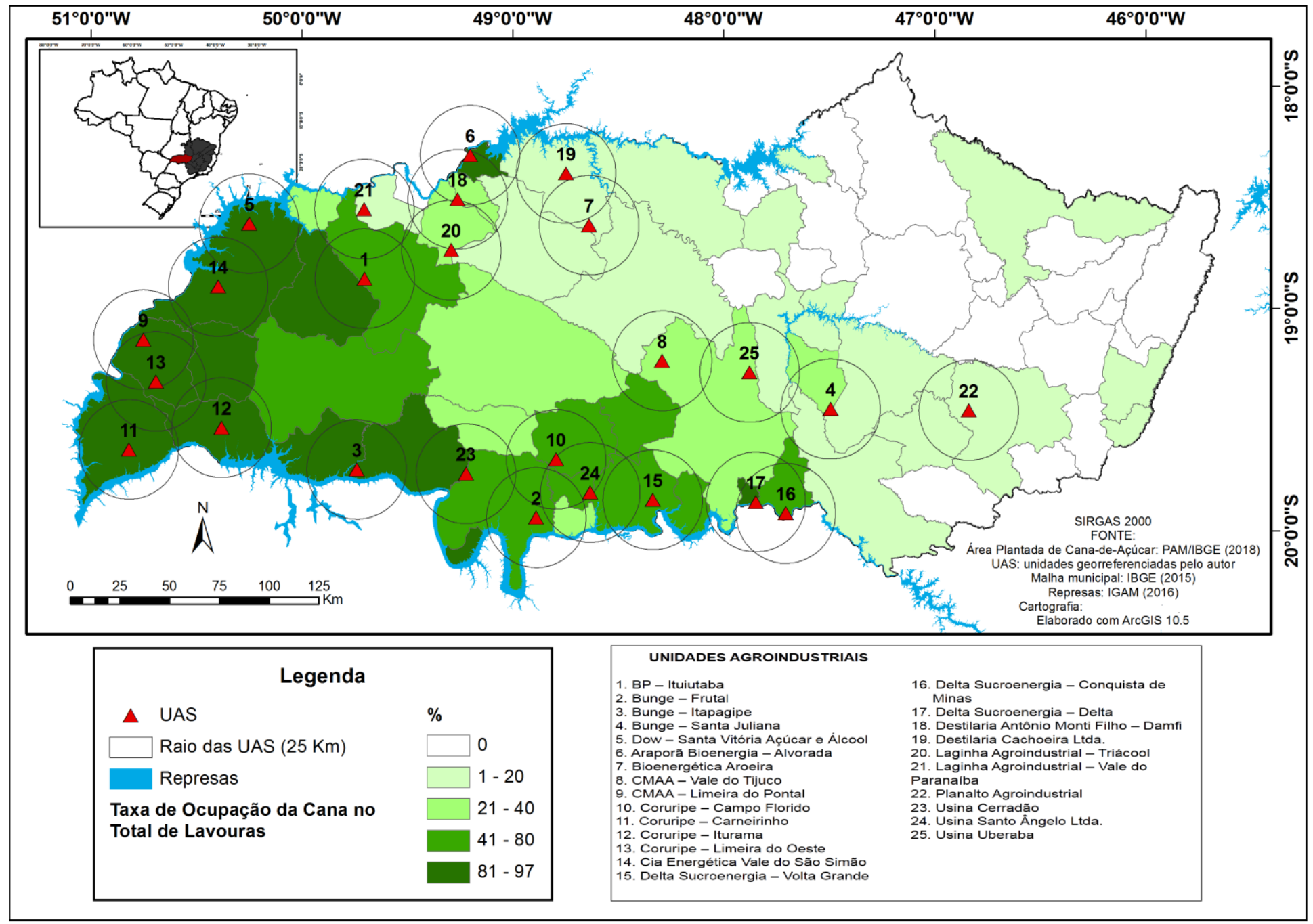

Fonte - Produção Agrícola Municipal - PAM (IBGE, 2018). Cartografia: SANTOS, Henrique. 
Ao cruzarmos essas informações de especialização produtiva com o número de habitantes, fica muito claro que boa parte desses municípios sucroenergéticos se encontram, grosso modo, altamente vulneráveis. A classificação dos municípios conforme o grau de vulnerabilidade territorial (VT) apresentada na Tabela 4 foi feita com base nos parâmetros descritos no Quadro 1.

Quadro 1 - Parâmetros de classificação do grau de vulnerabilidade territorial (VT) dos municípios sucroenergéticos.

\begin{tabular}{cccc}
\hline Nível de VT & $\begin{array}{c}\text { Patamar demográfico } \\
\text { (40 mil habitantes) }\end{array}$ & $\begin{array}{c}\text { Presença } \\
\text { de UAS }\end{array}$ & $\begin{array}{c}\text { Número de indicadores de especialização } \\
\text { territorial produtiva acima de 20\% }\end{array}$ \\
\hline Muito Alto & Abaixo & Sim & $6-7$ \\
\hline Alto & Abaixo & Sim & $3-5$ \\
\hline Médio & Abaixo & Não & $3-5$ \\
& Acima & Sim & $6-7$ \\
\hline Baixo & Abaixo & Não & $1-2$ \\
& Acima & Sim & $1-4$ \\
\hline
\end{tabular}

Elaboração - SANTOS, Henrique.

Consideramos que os municípios sucroenergéticos do Triângulo Mineiro/Alto Paranaíba com menos de 40 mil habitantes, que possuem UAS instaladas e apresentam mais de 3 indicadores razoáveis de especialização produtiva (acima de $20 \%$ ), que são os casos de Araporã, Campo Florido, Carneirinho, Conceição das Alagoas, Conquista, Delta, Frutal, Itapagipe, Iturama, Limeira do Oeste, Pirajuba, Santa Juliana, Santa Vitória, Tupaciguara e União de Minas; têm alto grau de vulnerabilidade territorial e estão propensos a fortes perturbações socioeconômicas em caso de eventual fechamento de UAS, como o que ocorreu nos municípios de Canápolis, Capinópolis, Fronteira e lbiá.

\section{Falências de UAS e implicações locais}

Nos últimos anos algumas UAS suspenderam definitivamente suas atividades produtivas no Triângulo Mineiro/Alto Paranaíba, afetando negativamente alguns municípios da região. $O$ caso mais problemático foram as do João Lyra, grupo que entrou em falência e desativou duas UAS em 2013: uma no município de Canápolis (Laginha Agroindustrial - Vale do Paranaíba) e outra no município de Capinópolis (Laginha Agroindustrial - Usina Triácool) (NOVACANA, 2017). Essas cidades, a primeira com 12 mil habitantes e a segunda com 16 mil habitantes, tiveram suas economias seriamente comprometidas com o encerramento das atividades agroindustriais, causando forte desemprego e colapso no comércio local. Juntas, as duas UAS tinham capacidade de processar 4,5 milhões de toneladas de cana-de-açúcar por safra e empregar mais de 6 mil pessoas. De acordo com uma reportagem do JornalCana (2014), a falência das unidades causou, além do desemprego em massa, prejuízo aos cofres públicos em uma dívida não paga (impostos) estimada em quase $R \$ 10$ milhões.

A partir de entrevistas realizadas junto às prefeituras e aos Sindicatos de Trabalhadores Rurais de Canápolis e Capinópolis, foi possível constatar que as duas UAS já vinham praticando irregularidades ambientais e trabalhistas, como desmatamentos com uso de queimadas, tratamento indevido de resíduos agroindustriais (vinhaça, torta de filtro, água de lavagem de cana), superexploração de cortadores de cana via pagamentos por produtividade, descumprimentos de acordos coletivos, etc. Mas outros problemas ocorreram após a falência do grupo, como atrasos e calotes de pagamentos a funcionários (férias, décimo terceiro, rescisão contratual, FGTS, INSS), a arrendantes de terras e a fornecedores (matéria-prima, maquinários e serviços), o que agravou a vulnerabilidade territorial desses municípios.

Outra usina desativada foi a Planalto Agroindustrial no município de Ibiá (24 mil habitantes), no início de 2013. Com capacidade de processar 700 mil toneladas de cana/safra, a empresa suspendeu as atividades por tempo indeterminado após passar por dificuldades financeiras, deixando mais de 450 pessoas sem emprego e com salários atrasados (G1, 2012). Já a Destilaria Rio Grande, com capacidade de moer 650 mil toneladas de cana/safra no município de Fronteira (16 mil habitantes),

Caminhos de Geografia $\quad$ Uberlândia $\quad$ v. 20, n. $72 \quad$ Dez/2019 $\quad$ p. 169-188 Página 182


encerrou definitivamente suas atividades em 2011, deixando mais de 380 pessoas desempregadas (DIÁRIO DA REGIÃO, 2011).

A Tabela 5 mostra a grande participação da agroindústria sucroenergética na economia agrícola, na arrecadação fiscal e no mercado de trabalho formal nos quatro municípios em 2009, demonstrando alta especialização territorial produtiva em época anterior à desativação das UAS.

Tabela 5 - Triângulo Mineiro/Alto Paranaíba: indicadores de especialização territorial produtiva dos municípios que tiveram UAS desativadas, 2009.

\begin{tabular}{c|cccccc}
\hline \multirow{2}{*}{ Municípios } & \multicolumn{5}{|c}{ Participação da cana-de-açúcar ou setor sucroenergético (\%) } \\
\cline { 2 - 6 } & $\begin{array}{c}\text { Área de } \\
\text { lavouras }{ }^{(1)}\end{array}$ & $\begin{array}{c}\text { Área do } \\
\text { município }\end{array}{ }^{(1)}$ & $\begin{array}{c}\text { Valor da produção } \\
\text { das lavouras }{ }^{(1)}\end{array}$ & $\begin{array}{c}\text { Arrecadação } \\
\text { fiscal (2) }\end{array}$ & $\begin{array}{c}\text { Empregos } \\
\text { formais }{ }^{(3)}\end{array}$ \\
\hline Canápolis & 83,3 & 27,4 & 61,3 & 61,4 & 5,5 \\
Capinópolis & 18,4 & 16,3 & 23,4 & 77,6 & 7,4 \\
Fronteira & 80,1 & 27,1 & 48,8 & 73,5 & 4,0 \\
Ibiá & 17,6 & 3,4 & 14,4 & 12,7 & 4,4 \\
\hline
\end{tabular}

Fontes - (1) PAM/IBGE (2018); (2) SEFAZ-MG (2018); (3) RAIS/MTE (2018). Organização: SANTOS, Henrique.

Já os dados da Tabela 6 mostram que após a desativação das UAS, a área e a quantidade produzida de cana-de-açúcar diminuíram substancialmente nos municípios. Pelo fato de várias empresas, sobretudo do setor de serviços, estarem direta ou indiretamente ligadas a dinâmica do setor sucroenergético, a falência das UAS também provocou o fechamento e a queda no número geral de empresas em atividade. Isso refletiu diretamente nas receitas e no número de empregos, que tiveram forte redução especialmente em Canápolis e Capinópolis (GAZETA DE ALAGOAS, 2016).

Tabela 6 - Triângulo Mineiro/Alto Paranaíba: área e produção de cana-de-açúcar e número de empresas ativas e vínculos empregatícios nos municípios que tiveram UAS desativadas, 2010, 2014 e 2016.

\begin{tabular}{|c|c|c|c|c|c|c|c|c|c|c|c|c|}
\hline \multirow[t]{2}{*}{ Variável } & \multicolumn{3}{|c|}{ Canápolis } & \multicolumn{3}{|c|}{ Capinópolis } & \multicolumn{3}{|c|}{ Fronteira } & \multicolumn{3}{|c|}{ Ibiá } \\
\hline & 2010 & 2014 & 2016 & 2010 & 2014 & 2016 & 2010 & 2014 & 2016 & 2010 & 2014 & 2016 \\
\hline Área de cana (mil ha) & 29,0 & 25,8 & 10,0 & 8,4 & 7,2 & 2,4 & 5,2 & 4,1 & 3,6 & 10,0 & 3,4 & 1,2 \\
\hline Produção de cana (mil t.) & 2.030 & 1.806 & 700 & 718 & 120 & 115 & 423 & 351 & 312 & 724 & 275 & 84 \\
\hline Empresas ativas & 270 & 235 & 234 & 457 & 405 & 387 & 398 & 379 & 355 & 705 & 566 & 562 \\
\hline Empregos (mil vínculos) & 3,3 & 2,0 & 1,6 & 3,6 & 2,7 & 2,4 & 1,8 & 1,6 & 1,6 & 4,1 & 4,5 & 4,4 \\
\hline
\end{tabular}

Fontes - Produção Agrícola Muncipal - PAM/IBGE (2018); IBGE Cidades (2018); RAIS/MTE (2018).

Organização: SANTOS, Henrique.

Portanto, é evidente que esses municípios tiveram grande fragilização econômica com a desativação das UAS, trazendo enormes impactos à população e aos governos locais. Os lugares agora convivem com a falta de empregos, dívidas das UAS com fornecedores (matéria-prima, bens e serviços), arrendantes de terras e trabalhadores (salários atrasados, direitos trabalhistas não pagos), e com a insuficiência de recursos públicos (provenientes em maior parte da atividade agroindustrial na forma de arrecadação fiscal) fundamental para as prefeituras manterem as despesas obrigatórias básicas da administração municipal e realizarem investimentos em melhorias nos serviços públicos e na infraestrutura das cidades.

\section{CONSIDERAÇÕES FINAIS}

Embora o setor sucroenergético tenha contribuído para a geração de emprego, renda e crescimento do PIB do agronegócio no Brasil, especialmente em pequenos municípios, a expansão agressiva que a atividade teve nos últimos anos representa, contraditoriamente, uma verdadeira ameaça à soberania e à autonomia técnica, econômica e política dos lugares funcionais à produção e/ou processamento da cana-de-açúcar. O padrão de ocupação altamente seletivo, engessado e

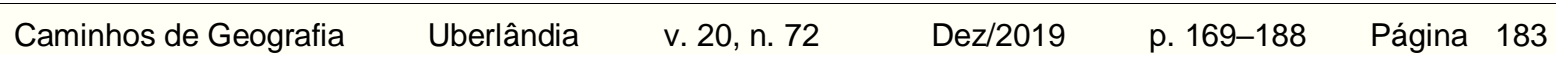


expropriador da agroindústria sucroenergética (CASTILLO, 2013; 2015) gera, do ponto de vista socioambiental, uma profunda acumulação despossessão/espoliação (HARVEY, 2005) que envolve a funcionalização de diversos ativos e recursos territoriais (BENKO e PECQUEUR, 2001) (terras, águas, mão de obra, infraestruturas logísticas, redes de serviços, benefícios fiscais, crédito estatal, etc.) a serviço da competitividade do setor. Isso acaba monopolizando completamente as regiões produtivas canavieiras através de vínculos de extrema dependência e alienação econômica à ordem corporativa e aos movimentos do mercado, sobretudo de pequenas municipalidades do interior dos estados de São Paulo, Minas Gerais, Goiás, Mato Grosso do Sul, Norte do Paraná e de demais estados produtores e processadores de cana-de-açúcar da região Norte-Nordeste.

O estudo da região do Triângulo Mineiro/Alto Paranaíba evidencia tal problemática de vulnerabilidade territorial associada à especialização regional produtiva provocada pela expansão do setor sucroenergético, principalmente em suas implicações socioambientais (CARVALHO, 2011; SOUZA, 2012; INÁCIO, 2014; CAMPOS, 2014; 2019; CLEPS JUNIOR, 2009; 2016). Conforme os dados puderam demonstrar, vários municípios desta região tornaram-se altamente dependentes da agroindústria sucroenergética em pouco período de tempo, na medida em que as lavouras de canade-açúcar ocuparam a maior parte das terras destinadas à agropecuária (reduzindo a diversidade produtiva no campo) e as UAS atrelaram a operação das atividades do setor secundário e terciário dos pequenos núcleos urbanos ao seu ritmo de funcionamento. Nesse contexto, o alto nível de propensão a sérios transtornos socioeconômicos ligados ao fechamento repentino das agroindústrias é uma realidade preocupante. O baixo patamar demográfico e o considerável nível de especialização territorial produtiva de boa parte dos municípios sucroenergéticos da região revelam um grau elevado de vulnerabilidade territorial, o que carece de maior atenção do poder público municipal e estadual.

É preciso considerar, porém, que tanto o nível de especialização territorial produtiva quanto a dinâmica econômica (que muito depende do tamanho das cidades e sua posição na rede urbana, além de outras características geográficas), influenciam nas condições dos municípios de resistirem ou de se recuperarem dos efeitos negativos ocasionados por eventuais crises sucroenergéticas locais. Tal ideia se fundamenta naquilo que Hudson (2009), Bristow (2010b), Martin (2012); Hamdouch et al. (2012), Boschma (2015) e Silva e Exterckoter (2016) têm chamado de resiliência territorial ou regional. Esse conceito, hoje muito utilizado nos estudos de economia regional, nos auxilia a mensurar o grau de vulnerabilidade territorial dos municípios sucroenergéticos, o que demanda, a partir desta perspectiva teórica, análises mais complexas de contextos locais e regionais. Sendo assim, o estudo vai muito além dos indicadores tratados neste artigo, incluindo vários outros dados e informações (primárias e secundárias), de caráter qualitativo e quantitativo, a serem analisados para chegarmos, de fato, a real situação de cada município. No que se refere à pesquisa apresentada, novos dados divulgados pelo Censo Agropecuário de 2017 devem ser analisados para diversificar e/ou aperfeiçoar os indicadores, sobretudo com relação à participação da cana-de-açúcar na economia rural (área agropecuária, produtores rurais, crédito rural, pessoal ocupado, valor da produção, uso de insumos e implementos agrícolas, entre outros).

Apesar de tais questões metodológicas, os casos de falências e fechamento de UAS nos municípios de Canápolis, Capinópolis, Fronteira e lbiá, além de vários outros exemplos espalhados pelo país, revelam a importância de atentarmos para a problemática que está por trás do processo de especialização regional produtiva efetivado pelo agronegócio sucroenergético, bem como dos impactos socioeconômicos da crise do setor aos municípios produtores. O contexto de centralização e financeirização do capital só tem agravado essa situação, ao passo que grupos empresariais sucroenergéticos menos capitalizados e eficientes (produção e logística moderna) e, portanto, menos competitivos (qualidade e custos), tendem a ter mais dificuldades de permanecer no mercado instável de açúcar e etanol (lógica das commodities), incorrendo elevados riscos de pedido de recuperação judicial, falências e fechamento de UAS (NOVACANA, 2019). Isto tem gerado um cenário de plena insegurança e vulnerabilidade dos municípios que hoje são muito dependentes economicamente do setor sucroenergético.

\section{AGRADECIMENTOS}

Agrademos a Fundação de Amparo à Pesquisa do Estado de São Paulo (FAPESP) pelo apoio financeiro concedido à pesquisa que originou este artigo.

$\begin{array}{lllll}\text { Caminhos de Geografia } & \text { Uberlândia } & \text { v. 20, n. } 72 & \text { Dez/2019 } & \text { p. 169-188 Página } 184\end{array}$




\section{REFERÊNCIAS}

ARROYO, M. A vulnerabilidade dos territórios latino-americanos: o papel das finanças. In: LEMOS, I. G.; SILVEIRA, M. L.; ARROYO, M. (Orgs.). Questões territoriais na América Latina. Buenos Aires: Editora Clacso, 2006.

BENKO, G. Economia, espaço e globalização na aurora do século XXI. São Paulo: Hucitec, 1996.

BENKO, G.; PECQUEUR, B. Os recursos de territórios e os territórios de recursos. Geosul, v. 16, n. 32, 2001, p. 31-50.

BOSCHMA, R. Towards an Evolutionary Perspective on Regional Resilience. Regional Studies, v. 49, n. 5, 2015, p. 733-751. https://doi.org/10.1080/00343404.2014.959481

BOSCHMA, R. Competitiveness of Regions from an Evolutionary Perspective. Regional Studies, v. 38, n. 9, 2004, p. 1001-1014. https://doi.org/10.1080/0034340042000292601

BRISTOW, G. Critical reflections on regional competitiveness: theory, policy and practice. New York: Routledge Studies in Human Geograpgy, 2010a. https://doi.org/10.4324/9780203865408

BRISTOW, G. Resilient regions: re-'place'ing regional competitiveness. Cambridge Journal of Regions, Economy and Society, v. 3, 2010b, p. 153-167. https://doi.org/10.1093/cjres/rsp030

BUDD, L.; HIRMIS, A. Conceptual Framework for Regional Competitiveness. Regional Studies, v. 38, n. 9, 2004, p. 1015-1028. https://doi.org/10.1080/0034340042000292610

CAMELINI, J. H. Regiões competitivas do etanol e vulnerabilidade territorial no Brasil: o caso emblemático de Quirinópolis, GO. Dissertação (Mestrado em Geografia). 159f. Campinas:

IG/UNICAMP, 2011.

CAMELINI, J. H.; CASTILLO, R. Etanol e Uso Corporativo do Território. Mercator, v. 11, n. 25, mai./ago. 2012, p. 7-18. https://doi.org/10.4215/RM2012.1125.0001

CAMPOS, N. L. Internacionalização do capital no setor sucroenergético do Triângulo Mineiro/Alto Paranaíba: estratégias políticas e territoriais. Tese (Doutorado em Geografia). $258 f$. Uberlândia: IG/UFU, 2019.

CAMPOS, N. L. Redes do Agronegócio Canavieiro: a territorialização do Grupo Tércio Wanderley no Triângulo Mineiro/Alto Paranaíba - MG. Dissertação (Mestrado em Geografia). 209f. Uberlândia: IG/UFU, 2014.

CARVALHO, N. D. Luta pela terra no Triângulo Mineiro/Alto Paranaíba: a trajetória dos movimentos e organizações sociais na construção do território. Dissertação (Mestrado em Geografia). 140f. Uberlândia: IG/UFU, 2011.

CASTILLO, R. Dinâmicas recentes do setor sucroenergético no Brasil: competitividade regional e expansão para o bioma Cerrado. Revista GEOgraphia, n. 35, 2015, p. 95-119.

https://doi.org/10.22409/GEOgraphia2015.v17i35.a13730

CASTILLO, R. A expansão do setor sucroenergético no Brasil. In: BERNARDES, J. A.; SILVA, C. A.; ARRUZZO, R. C. (Org.). Espaço e energia: mudanças no paradigma sucroenergético. Rio de Janeiro: Lamparina, 2013, p. 75-84.

CASTILLO, R. Agricultura globalizada e logística nos cerrados brasileiros. In: SILVEIRA, M. R. (org.). Circulação, transportes e logística: diferentes perspectivas. São Paulo: Outras Expressões, 2011.

CASTILLO, R.; FREDERICO, S. Dinâmica regional e globalização: espaços competitivos agrícolas no território brasileiro. Mercator, v. 9, n. 18, jan./abr. 2010, p. 17-26.

https://doi.org/10.4215/RM2010.0918.0002

CASTILLO, R.; FREDERICO, S. Espaço geográfico, produção e movimento: uma reflexão sobre o conceito de circuito espacial produtivo. Sociedade \& Natureza, Uberlândia, 22 (3): 461-474, dez. 2010b. https://doi.org/10.1590/S1982-45132010000300004

CHESNAIS, F. (Org.) A finança mundializada. São Paulo: Boitempo, 2005. 
CLEPS JUNIOR, J. Expansão e territorialização das agroindústrias do setor sucroenergético em Minas Gerais e o contexto das lutas sociais no campo. Revista Geonordeste, v. 27, p. 123-137, 2016.

CLEPS JUNIOR, J. Concentração de poder no agronegócio e (des)territorialização: os impactos da expansão recente do capital sucroalcooleiro no Triângulo Mineiro. Caminhos de Geografia, v. 10, n. 31, p. 249-264, 2009.

DIÁRIO DA REGIÃO. Usina de álcool em Fronteira demite $\mathbf{3 8 0}$ trabalhadores. Reportagem, 25/01/2011. Disponível em: https://goo.gl/q0Tulp. Acesso em: Junho/2016.

ELIAS, D. Agronegócio globalizado e (re)estruturação urbano-regional. In: ENCONTRO NACIONAL DA ANPUR (ENANPUR). Anais. São Paulo: USP, 2017.

ELIAS, D. Regiões produtivas do agronegócio: notas teóricas e metodológicas. In: BERNARDES, J. A., SILVA, C. A., ARRUZZO, R. C. (Orgs.) Espaço e energia: mudanças no paradigma sucroenergético. 1aㅡ Ed. Rio de Janeiro: Lamparina, 2013, p. 201-220.

FREDERICO, S. Agricultura científica globalizada e fronteira agrícola moderna no Brasil. Revista Confins. Paris, v. 17, 2013, p. 1-17. https://doi.org/10.4000/confins.8153

G1. Fechamento de usina em Ibiá, MG, deixa 450 trabalhadores desempregados. Reportagem, 01/03/2012. Disponível em: https://goo.gl/GtiLno. Acesso em: dezembro/2016.

GAVIRA, M. de O. Sustentabilidade Ambiental do Setor Sucroenergético. In: SALLES-FILHO, Sérgio (Org.). Futuros do bioetanol: o Brasil na liderança? Rio de Janeiro: Elsevier, 2015, p. 71-90.

GAZETA DE ALAGOAS. MG quer celeridade em julgamento. Reportagem, 07/07/2016. Disponível em: https://goo.gl/AxCwvm. Acesso em: janeiro/2018.

GOMES, R. Empresas Transnacionais e Internacionalização da P\&D: elementos de organização industrial da economia da inovação. São Paulo: Editora da UNESP, 2006.

HAMDOUCH, A.; DEPRET, M.; TANGUY, C. (Eds.). Mondialisation et resilience des territoires: Trajectoires, dynamiques d'acteurs et experiences locales. Presses de l'Université du Québec, Québec, 2012.

HARVEY, D. $O$ enigma do capital: e as crises do capitalismo. Trad. João Alexandre Peschanski. São Paulo: Boitempo, 2011.

HARVEY, D. (2005). O Neoliberalismo: história e implicações. Trad. Adail Ubirajara Sobral, Maria Stela Gonçalves. 2. ed. São Paulo: Edições Loyola, 2011. https://doi.org/10.1038/ijo.2010.171

HIRST, P.; THOMPSON, G. Globalização em questão: a economia internacional e as possibilidades de governabilidade. Petrópolis: Vozes, 1998.

HUDSON, R. Resilient regions in an uncertain world: wishful thinking or a practical reality?

Cambridge Journal of Regions, Economy and Society, 2009, p. 1-15.

https://doi.org/10.1093/cjres/rsp026

INÁCIO, J. B. Contradições e tensões no processo de expansão do setor sucroenergético em Iturama-MG. Dissertação (Mestrado em Geografia). 157f. Uberlândia: IG/UFU, 2014.

JORNALCANA. Fechamento de usinas afeta economias de cidades do Triângulo. Reportagem, 15/08/2014. Disponível em: https://goo.gl/26UOBh. Acesso em: Julho/2016.

KEMENY, T.; STORPER, M. Is Specialization Good for Regional Economic Development? Regional Studies, v. 49, n. 6, 2015, p. 1003-1018. https://doi.org/10.1080/00343404.2014.899691

KITSON, M.; MARTIN, R.; TYLER, P. Regional Competitiveness: An Elusive yet Key Concept? Regional Studies, v. 38, n. 9, 2004, p. 991-999. https://doi.org/10.1080/0034340042000320816

MARTIN, R. Regional economic resilience, hysteresis and recessionary shocks. Journal of Economic Geography, v. 12, 2012, p. 1-32. https://doi.org/10.1093/jeg//br019

MENDONÇA, M. L.; PITTA, F. T.; XAVIER, C. V. A Agroindústria Canavieira e a Crise Econômica Mundial. São Paulo: Outras Expressões, 2012. Disponível em: www.social.org.br. Acesso em: Julho/2016.

\begin{tabular}{lllll}
\hline Caminhos de Geografia & Uberlândia & v. 20, n. 72 & Dez/2019 & p. 169-188 Página 186
\end{tabular}


NOVACANA. Em 2019, 23\% das usinas brasileiras de cana-de-açúcar estarão paradas. Reportagem, 05/04/2019. Disponível em: https://bit.ly/2WNAorS. Acesso em: abr./2019.

NOVACANA. João Lyra vai ao STJ contra falência de suas usinas. Reportagem, 21/02/2017. Disponível em: https://goo.gl/OIAhlj. Acesso em: março/2017.

PEREIRA, M. F. V. As 'cidades da cana' no Triângulo Mineiro (Brasil): para uma discussão das implicações territoriais do agronegócio e de seus nexos urbanos. In: $15^{\circ}$ ENCUENTRO DE GEÓGRAFOS DE AMÉRICA LATINA. Anais. La Habana: Universidad La Habana, 2015.

PEREIRA, M. F. V. Os agentes do agronegócio e o uso do território no Triângulo Mineiro/Alto Paranaíba: da moderna agricultura de grãos à expansão recente da cana-de-açúcar. Revista do Departamento de Geografia - USP, vol. 23, p. 83-104, 2012.

https://doi.org/10.7154/RDG.2012.0023.0004

PETRONZIO, J. A. C. A expansão canavieira na mesorregião Triângulo Mineiro/Alto Paranaíba de 2000 a 2013. Dissertação (Mestrado em Geografia). 95f. Uberlândia: IG/UFU, 2014.

PITTA, F. T.; XAVIER, C. V.; NAVARRO, C.; MENDONÇA, M. L. Empresas Transnacionais e Produção de Agrocombustíveis no Brasil. São Paulo: Outras Expressões, 2014. Disponível em: www.social.org.br. Acesso em: Julho/2016.

PROCANA. Anuário da Cana: Brazilian Sugar and Etanol Guide. 2016. Ribeirão Preto, 2016.

REIS, L. N. G. Mapeamento multitemporal e conversão do uso da terra a partir da expansão canavieira no Triângulo Mineiro (2000-2010). Dissertação (Mestrado em Geografia). $126 f$. Uberlândia: IG/UFU, 2013.

RUDORFF, B.F.T.; AGUIAR, D.A.; SILVA, W.F.; SUGAWARA, L.M.; ADAMI, M.; MOREIRA, M.A. Studies on the Rapid Expansion of Sugarcane for Ethanol Production in São Paulo State (Brazil) Using Landsat Data. Remote Sens, v. 2, p. 1057-1076, 2010. https://doi.org/10.3390/rs2041057

SANTOS, H. F. Modernização da agricultura e dinâmica do agronegócio globalizado no Triângulo Mineiro/Alto Paranaíba. Geografia em Questão, v. 12, n. 1, p. 9-36, 2019.

SANTOS, H. F. Competitividade regional do setor sucroenergético na mesorregião Triângulo Mineiro/Alto Paranaíba: agricultura científica globalizada e implicações socioambientais no município de Uberaba - MG. Dissertação (Mestrado em Geografia). 281f. Campinas: IG/UNICAMP, 2017a. https://doi.org/10.33081/formacao.v1i25.5025

SANTOS, M. (2000) Por uma outra globalização: do pensamento único à consciência universal. 19 ed. Rio de Janeiro: Record, 2010.

SANTOS, M. Circuitos espaciais da produção: um comentário. In: SOUZA, M. A. A.; SANTOS, M. (Org.). A construção do espaço. São Paulo: Nobel, 1986. p. 121-134.

SANTOS, M.; SILVEIRA, M. L. (2001) O Brasil: território e sociedade no início do século XXI. $13^{\circ}$ ed. São Paulo: Record, 2010.

SCOTT, A; STORPER, M. Regions, Globalization, Development. Regional Studies, v. 37, 2003, p. 579-593. https://doi.org/10.1080/0034340032000108697a

SILVA, C. A. da; EXTERCKOTER, R. K. Resiliência: contribuições e desafios para o estudo do desenvolvimento das regiões. GEOgraphia, v. 18, n. 37, p. 115-137.

https://doi.org/10.22409/GEOgraphia2016.1837.a13761

SILVEIRA, M. L. Território Usado: dinâmicas de especialização, dinâmicas de diversidade. Ciência Geográfica. Bauru, v. XV, n. 1, 4-12, jan./dez. 2011.

SILVEIRA, M. L. Região e Globalização: pensando um esquema de análise. Redes. Santa Cruz do Sul, v. 15, n. 1, p. 74-88, jan./abr. 2010.

SOUZA, A. G. A territorialização do agronegócio canavieiro em Frutal-MG. Dissertação (Mestrado em Geografia). 187f. Uberlândia: IG/UFU, 2012.

STACCIARINI, J. H. S.; PEREIRA, M. F. V. O Setor sucroenergético no Triângulo Mineiro: crescimento econômico e manutenção das desigualdades sociais nas "cidades da cana". Ateliê Geográfico, v. 12, n. 3, p. 55-75, dez./2018. https://doi.org/10.5216/ag.v12i3.46969

$\begin{array}{lllll}\text { Caminhos de Geografia } & \text { Uberlândia } & \text { v. 20, n. } 72 & \text { Dez/2019 } & \text { p. 169-188 Página } 187\end{array}$


SZMRECSÁNYI, T.; GONÇALVES, D. B. Efeitos Socioeconômicos e Ambientais da Expansão da Lavoura Canavieira no Brasil. In: XXVIII CONGRESSO DA ASSOCIAÇÃO DE ESTUDOS LATINOAMERICANOS. Rio de Janeiro: LASA, 2009.

THOMAZ JÚNIOR, A. Dinâmica Geográfica do Trabalho no Século XXI (Limites Explicativos, Autocrítica e Desafios Teóricos). Tese de Livre Docência. 941f. Presidente Prudente: FCT/UNESP, 2009.

Recebido em: 15/06/2018

Aceito para publicação em: 26/11/2019 